\title{
PENGARUH KEPEMIMPINAN KEPALA SEKOLAH DAN KOMPETENSI GURU TERHADAP MOTIVASI KERJA GURU SERTA IMPLIKASINYA PADA KINERJA GURU DI SMP NEGERI KOTA PALEMBANG
}

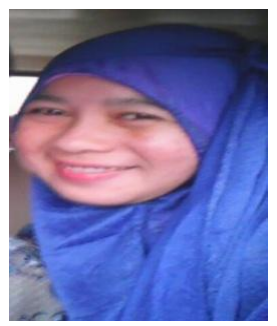

\author{
Oleh : \\ RA. Zubaidah \\ Pegawai Dinas Pendidikan Kabupaten OKI \\ Email : ra.zubaida_kag@yahoo.com
}

\begin{abstract}
Abstrak
Penelitian ini bertujuan untuk menganalisis dan mengetahui Pengaruh Kepemimpinan Kepala Sekolah dan Kompetensi Guru Terhadap Motivasi Kerja Guru Serta Implikasinya Pada Kinerja Gurudi SMP Negeri Kota Palembang.

Populasi dalam penelitian ini berjumlah sebesar 2668 guru SMPN Kota Palembang,sedangkan sampel 340 guru sesuai persyaratan SEM.

Analisis hasil penelitian menggunakan metode statistik deskriptif dan inferensial untuk menyimpulkan adanya pengaruh variabel eksogen terhadap variabel endogen baik secara simultan maupun parsial. Model analisis menggunakan Structure Equation Model (SEM) dengan komposisi sub-struktur :Kepemimpinan kepala sekolah (X1) dan kompetensi guru (X2) sebagai variabel eksogen dan Motivasi Kerja (Y) sebagai variabel endogen . Struktur 2 terdiri dari : Kepemimpinan kepala sekolah (X1), Kompetensi guru (X2), dan Motivasi Kerja guru(Y) sebagai variabel eksogen dan Kinerja Guru(Z) sebagai variabel endogen.

Hasil penelitian menunjukkan sebagai berikut :(1) Secara parsial terdapat pengaruh positif dan signifikan kepemimpinan kepala sekolah terhadap motivasi kerja guru di SMP Negeri kota Palembang,(2) Secara parsial terdapat pengaruh positif dan signifikan kompetensi guru terhadapmotivasi kerja guru di SMP Negeri kota Palembang,(3)Terdapat pengaruh positif kepemimpinan kepala sekolah dan kompetensi guru secara bersama-sama terhadap motivasi kerja guru di SMP Negeri kota Palembang, (4) Secara parsial terdapat pengaruh positif dan signifikan motivasi kerja terhadap kinerja guru di SMP Negeri kota Palembang,(5) Secara parsial terdapat pengaruh positif dan signifikan kepemimpinan kepala sekolah terhadap kinerja guru di SMP Negeri kota Palembang,(6) Secara parsial terdapat pengaruh positif dan signifikan kompetensi guru terhadap kinerja guru di SMP Negeri kota Palembang,(7) Terdapat pengaruh positif kepemimpinan kepala sekolah, kompetensi guru dan motivasi kerja guru secara bersama-sama terhadap kinerja guru di SMP Negeri kota Palembang.

Hasil penelitian ini menggambarkan bahwa untuk meningkatkan kinerja guru SMPN Kota Palembang maka perlu lebih meningkatkan kompetensi guru .Sedangkan untuk meningkatkan motivasi kerja guru SMPN Kota Palembang, faktor kepemimpinan kepala sekolah memiliki peran yang paling besar.
\end{abstract}

Kata Kunci : Kepemimpinan Kepala Sekolah, Kompetensi, Motivasi Kerja, dan Kinerja

\section{A. PENDAhULUAN}

Kunci pembangunan masa mendatang bagi bangsa Indonesia ialah pendidikan (Kartono,2007:1).Lembaga pendidikan merupakan suatu organisasi non profit yang didalamnya terdiri dari beberapa macam komponen, salah satu komponen yang paling penting adalah tenaga pendidik selaku Sumber Daya Manusia (SDM) dan kepala sekolah selaku manajer SDM Sedangkan tujuan yang akan dicapai organisasi ini adalah keberhasilan dalam mendidik semua pelajar yang ada di lingkungan sekolah tersebut.

Hasil penelitian Suyanto HD dalam Efendi. A (2007: 43) mengungkapkan angkatan kerja di Indonesia (a) yang tidak berpendidikan 53\%; (b) Pendidikan SD 
34\%; (c) Pendidikan Menengah $11 \%$. Dalam suatu fenomena yang lain, permasalahan yang muncul ke permukaan sekarang adalah rendahnya mutu pendidikan, salah satunya adalah rendahnya kinerja guru, faktor penyebab rendahnya kinerja guru adalah guru yang belum menguasai kompetensi guru, dengan indikator kepribadian (kemampuan kepribadian guru) ,pedagogik (kemampuan dalam pengelolaan peserta didik),sosial (kemampuan pendidik sebagai bagian dari masyarakat),dan propesional (kemampuan penguasaan materi pembelajaran). Pengaruh kompetensi guru di dalam pendidikan dapat digambarkan dengan melihat kebutuhan guru di sekolah, di manamasih ada guru yang mengajar bukan pada bidangnya . Berdasarkan tabel 1.1 berikut ini :

\section{Tabel 1.1.Kebutuhan Guru SMPN Per} Mata PelajaranDi Kota Palembang

\begin{tabular}{|l|l|l|l|l|l|}
\hline No & Mata pelajaran & Kebutuhan & $\begin{array}{c}\text { Guru } \\
\text { yang } \\
\text { ada }\end{array}$ & $\begin{array}{c}\text { Kekur } \\
\text { angan }\end{array}$ & $\begin{array}{c}\text { Kele } \\
\text { bihan }\end{array}$ \\
\hline 1 & $\begin{array}{l}\text { Pendidikan } \\
\text { agama }\end{array}$ & 121 & 145 & - & 24 \\
\hline 2 & Pkn & 117 & 148 & - & 31 \\
\hline 3 & Bahasa Indonesia & 281 & 370 & - & 89 \\
\hline 4 & Matematika & 295 & 378 & - & 83 \\
\hline 5 & IPS Terpadu & 282 & 371 & - & 89 \\
\hline 6 & IPA Terpadu & 274 & 340 & - & 66 \\
\hline 7 & Bahasa inggris & 239 & 263 & - & 24 \\
\hline 8 & Seni budaya & 129 & 103 & 26 & - \\
\hline 9 & Penjaskes & 118 & 108 & 10 & - \\
\hline 10 & Tik & 103 & 26 & 77 & - \\
\hline 11 & Keterampilan & 54 & 29 & 25 & - \\
\hline 12 & Mulok & 110 & 42 & 68 & - \\
\hline 13 & BP/BK & 245 & 206 & 39 & - \\
\hline Jumlah & 2.368 & 2.529 & 245 & 406 \\
\hline 14 & Guru Dp & 229 & - & - \\
\hline Total & Sumber: Dinas & Pendidikan, & - & - \\
\hline
\end{tabular}

Sumber: Dinas Pendidikan, Pemuda Dan Olahraga Kota Palembang, 2011.

Dari tabel tersebut dapat di simpulkan bahwa kekurangan guru berjumlah 245 guru dari 7 mata pelajaran yaitu : pendidikan agama,pkn,bahasa indonesia, matematika, IPS Terpadu, IPA Terpadu, bahasa inggris. Sedangkan kelebihan guru berjumlah 406 guru dari 6 mata pelajaran yaitu: seni budaya, penjaskes, TIK, keterampilan, Mulok, $\mathrm{Bp} / \mathrm{Bk}$. Mata pelajaran yang kekurangan guru dapat di ajar oleh guru yang tidak mengajar pada mata pelajaran yang sesungguhnya karena kelebihan guru tersebut.

Ternyata rendahnya motivasi kerja guru pada SMPN kota Palembang adalah diduga karena rendahnya kompetensi kerja guru dan kurang optimalnya kinerja guru dalam melakukan pekerjaan di duga karena rendahnya kepemimpinan di sekolah dan motivasi kerja guru. Salah satu untuk meningkatkan kinerja dengan melalui kompetensi guru ,maka di harapkan meningkatkan kemampuan yaitu melalui kemampuan dalam pengelolaan peserta didik (pedagogik), kemampuan kepribadian ,kemampuan pendidik sebagai bagian dari masyarakat dan kemampuan pendidik sebagai bagian dari masyarakat (sosial), serta kemampuan penguasaan materi pembelajaran (profesional) yang akan menghasilkan manajemen yang efektif.

Berdasarkan uraian di atas maka perlu dilakukan penelitian mengenai pengaruh kepemimpinan kepala sekolah dan kompetensi guru terhadap motivasi kerja guru serta implikasinya pada kinerja guru di SMP Negeri kota Palembang.

\section{B. RUMUSAN MASALAH}

Berdasarkan identifikasi masalah di atas, maka dapat disusun sejumlah rumusan masalah sebagai berikut :

1. Apakah terdapat pengaruh kepemimpinan kepala sekolah terhadap motivasi kerja guru di Sekolah 
Menengah Pertama Negeri Kota Palembang?

2. Apakah terdapat pengaruh kompetensi guru terhadap motivasi kerja guru di Sekolah Menengah Pertama Negeri Kota Palembang?

3. Apakah terdapat pengaruh kepemimpinan kepala sekolah dan kompetensi guru guru terhadap motivasi kerja guru di Sekolah Menengah Pertama Negeri Kota Palembang?

4. Apakah terdapat pengaruh motivasi kerja terhadap kinerja guru di Sekolah Menengah Pertama Negeri Kota Palembang?

5. Apakah terdapat pengaruh kepemimpinan kepala sekolah terhadap kinerja guru di Sekolah Menengah Pertama Negeri Kota Palembang?

6. Apakah terdapat pengaruh kompetensi guru terhadap kinerja guru di Sekolah Menengah Pertama Negeri Kota Palembang?

7. Apakah terdapat pengaruh kepemimpinan kepala sekolah, kompetensi guru dan motivasi kerja guru secara bersama-sama terhadap kinerja guru di Sekolah Menengah Pertama Negeri Kota Palembang?

\section{TUJUAN PENELITIAN}

Berdasarkan rumusan masalah di atas, maka dapat disusun sejumlah tujuan penelitian sebagai berikut :

1.1 Tujuan penelitian secara deskriptif, yaitu untuk mengetahui karakteristik Setiap variabel yang berkaitan dengan pengumpulan dan penyajian data sehingga dapat memberikan informasi yang bermanfaat.

1.2 Tujuan penelitian secara inferensial, yaitu untuk menguji dan menganalisis:
1. Pengaruh kepemimpinan kepala sekolah terhadap motivasi kerja guru di Sekolah Menengah Pertama Negeri Kota Palembang.

2. Pengaruh kompetensi guru terhadap motivasi kerja guru di Sekolah Menengah Pertama Negeri Kota Palembang.

3. Pengaruh kepemimpinan kepala sekolah dan kompetensi guru terhadap motivasi kerja guru di Sekolah Menengah Pertama Negeri Kota Palembang.

4. Pengaruh motivasi kerja guru terhadap kinerja guru di Sekolah Menengah Pertama Negeri Kota Palembang.

5. Pengaruh kepemimpinan kepala sekolah terhadap kinerja guru di Sekolah Menengah Pertama Negeri Kota Palembang.

6. Pengaruh kompetensi guru terhadap kinerja guru di Sekolah Menengah Pertama Negeri Kota Palembang.

7. Pengaruh kepemimpinan kepala sekolah, kompetensi guru dan motivasi kerja guru secara bersamasama terhadap kinerja guru di Sekolah Menengah Pertama Negeri Kota Palembang.

\section{A. Landasan Teori}

\section{1. kepemimpinan KepalaSekolah}

Kepemimpinan kepala sekolah dalam penelitian ini adalah kemampuan kepala sekolah di dalam mempengaruhi bawahannya untuk melaksanakan tugas sesuai dengan tujuan yang telah ditetapkan, (Owens, 2001). Adapun dimensi kepemimpinan kepala sekolah terdiri dari dua dimensi, yaitu : kepemimpinan berorientasi pada tugas (task oriented) dan kepemimpinan berorientasi pada hubungan manusia (people oriented). 
Dimensi kepemimpinan berorientasi pada tugas (task oriented) dikembangkan menjadi beberapa indikator : a.penyusunan rencana kerja , b. penetapan pola kerja, c. prosedur pencapaian tujuan, d.Target kerja. Dimensi kepemimpinan berorientasi pada hubungan manusia (people oriented) memilki indikator sebagai berikut : a. Hubungan kesejawatan b.Saling mempercayai c. Saling menghargai d. Kehangatan hubungan antar anggota.

\section{Kompetensi Guru}

\section{Kompetensi guru adalah kemampuan seorang guru dalam melaksanakan kewajiban-kewajibannya secara bertanggung jawab dan layak (Muhibbin Syah, 2007). dimensi dari kompetensi adalah pedagogik, kepribadian, sosial dan profesional yang dikembangkan menjadi indikator-indikator sebagai berikut :}

\section{Dimensi kompetensi pedagogic} dengan indikator-indikator: (a) pemahaman wawasan atau landasan kependidikan; (b) pemahaman terhadap peserta didik; (c) pengembangan kurikulum/ silabus; (d) perancangan pembelajaran; (e) pelaksanaan pembelajaran yang mendidik dan dialogis; (f) evaluasi hasil belajar; dan (g)pengembangan peserta didik untuk mengaktualisasikan berbagai potensi yang dimilikinya. Dimensi kompetensi kepribadian dengan indikatorindikator:(a) mantap; (b) stabil; (c) dewasa; (d) arif dan bijaksana; (e) berwibawa; (f) berakhlak mulia; (g) menjadi teladan bagi peserta didik dan masyarakat; (h) mengevaluasi kinerja sendiri; dan (i) mengembangkan diri secara berkelanjutan. Dimensi kompetensi sosial dengan indikatorindikator: (a) berkomunikasi lisan dan tulisan; (b) menggunakan teknologi komunikasi dan informasi secara fungsional; (c) bergaul secara efektif dengan peserta didik, sesama pendidik, tenaga kependidikan, orangtua/wali peserta didik; dan (d) bergaul secara santun dengan masyarakat sekitar. Dimensi kompetensi profesional dengan indikator-indikator : (a) konsep, struktur, dan metoda keilmuan/teknologi/seni yang menaungi/koheren dengan materi ajar; (b) materi ajar yang ada dalam kurikulum sekolah; (c) hubungan konsep antar mata pelajaran terkait; (d) penerapan konsepkonsep keilmuan dalam kehidupan seharihari; dan (e) kompetisi secara profesional dalam konteks global dengan tetap melestarikan nilai dan budaya nasional.

\section{Motivasi Kerja Guru}

Motivasi kerja guru dalam penelitian ini adalah keinginan kerja guru untuk mencapai tujuan atau prestasi, yang dapat berpengaruh membangkitkan, mengarahkan dan memelihara perilaku yang berhubungan dengan lingkungan kerja, (Mc.Clelland, 2001). Adapun dimensi motivasi kerja terdiri dari tiga dimensi yaitu : kebutuhan untuk berprestasi, berafiliasi dan kekuasaan. Dimensi kebutuhan berprestasi memiliki indikator sebagai berikut : (a) tingkat upaya untuk berprestasi baik, (b) tingkat upaya untuk tidak ketinggalan oleh pegawai lain dalam prestasi, (c) tingkat upaya mengembangkan diri, (d) tingkat upaya untuk mendapatkan pengakuan dari hasil kerja, (e) tingkat semangat untuk mendapatkan informasi terkini, (f) tingkat kemampuan menghadapi kesulitan ; Dimensi kebutuhan untuk berafiliasi meliputi indikator-indikator sebagai berikut : (a) tingkat semangat untuk berafiliasi dengan lingkungannya (b) 
tingkat semangat untuk dapat bekerjasama, (c) tingkat semangat mematuhi segala aturan yang ada, (d) tingkat semangat untuk disiplin pada waktu, (e) tingkat usaha untuk menjaga persahabatan dengan teman sekerja dan (f) selalu menghormati pimpinan. Dimensi kebutuhan untuk kekuasaan meliputi indikator-indikator (a) tingkat berusaha agar dirinya dihargai, (b) tingkat upaya untuk tidak diremehkan, (c) tingkat kehadiran sangat diperlukan orang lain, dan (d) tingkat berusaha untuk selalu menjaga wibawa.

\section{Kinerja Guru}

Kinerja guru dalam penelitian ini adalah hasil kerja yang dapat dicapai oleh seorang guru di sekolah sesuai dengan tugas dan tanggung jawabnya dalam mencapai tujuan pendidikan (Mitchell terence, 2010).

Adapun kinerja guru memiliki 5 dimensi yaitu kualitas kerja, kecepatan dan ketepatan, inisiatif, kemampuan, komunikasi.

1. Dimensi Kualitas Kerja, Indikatornya: a. Merencanakan program pengajaran dengan tepat; b. Menerapkan hal-hal yang baru dalam pembelajaran; c. Memberikan materi ajar sesuai dengan karakteristik yang dimiliki siswa; d. Menerapkan hasil penelitian dalam pembelajaran

\section{Dimensi Ketepatan/Kecepatan Kerja,} Indikator: a.Berhati-hati dalam menjelaskan materi ajaran; b. Melakukan penilaian hasil belajar dengan teliti;c. Menyelesaikan program pengajaran sesuai dengan kalender akademik.

\section{Dimensi Inisiatif Dalam Bekerja} Indikator: a. Menggunakan media dalam pembelajaran; b. Menggunakan berbagai metode dalam pembelajaran; $c$. Menyelenggarakan administrasi sekolah dengan baik; d. Menciptakan hal-hal yang baru yang lebih efektif dalam menata administrasi sekolah.

\section{Dimensi Kemampuan Dalam Bekerja} Indikator: a. Mampu dalam memimpin kelas; b. Mampu mengelola interaksi belajar mengajar; c. Mampu melakukan penilaian hasil belajar siswa; d. Menguasai landasan pendidikan.

5. Dimensi Komunikasi Indikator: a. Melaksanakan layanan bimbingan belajar; b. Mengkomunikasikan hal-hal yang baru dalam pembelajaran; c. Menggunakan berbagai teknik dalam mengelola proses belajar mengajar; d. Terbuka dalam menerima masukan guna perbaikan pembelajaran.

\section{B. METODE PENELITIAN}

\section{Lokasi Penelitian}

Penelitian ini dilaksanakan pada 55 SMP Negeri se Kota Palembang.

\section{Populasi Dan Sampel}

Populasi Pada penelitian ini, ukuran populasi adalah para guru pada Sekolah Menengah Pertama (SMP) Negeri di kota Palembang yang berjumlah 55 SMP Negeri dengan jumlah guru 2668 orang Dinas Pendidikan. Pemuda dan Olahraga (Kota Palembang, 2011). Jumlah sampel juga dapat ditentukan dengan 5 - 10 sampel per parameter. Dalam penelitian ini terdapat 4 konstruk dengan total 68 parameter. Berdasarkan ketentuan-ketentuan di atas maka jumlah minimum sampel yang akan di ambil dalam penelitian ini sebanyak 5 x $68=340$ responden dari semua guru yang berada di SMP Negeri Palembang.

\section{Teknik Pengumpulan Data}

Jenis data yang dikumpulkan dalam penelitian disertasi ini terdiri dari 
sumber data primer dan sumber data sekunder. Data primer bersumber dari jawaban kuesioner yang diberikan oleh responden dan melakukan wawancara. Sedangkan data sekunder untuk penelitian disertasi ini diperoleh dari berbagai sumber seperti: Disertasi yang berhubungan subtansi penelitian, jurnal penelitian yang berhubungan dengan subtansi penelitian, website/internet, peraturan pemerintah tentang guru dan dosen, dokumen laporan hasil dinas pendidikan palembang.

\section{Teknik Analisis Data}

\section{a. Uji validitas}

Uji validitas digunakan untuk mengetahui sah/valid tidaknya suatu kuisioner, suatu kuisioner dinyatakan valid jika pertanyaan pada kuisioner mampu mengungkapkan sesuatu yang akan diukur oleh kuisioner tersebut (Ghozali dan Fuad, 2008:142). Tingkat validitas dapat diukur dengan cara membandingkan nilai $r$ hitung dengan nilai $r$ tabel untuk Degree Of Freedom $(\mathrm{df})=\mathrm{n}$. Dengan pertanyaaan tersebut dikatakan valid jika $r_{\text {hitung }}>t_{\text {tabel }}$ dan sebaliknya jika $r_{\text {hitung }}<t_{\text {tabelmaka }}$ pertanyaaan tersebut tidak valid. Selain itu juga validitas digunakan untuk melihat apakah responden dapat memahami pertanyaaan yang ada, sehingga hasilnya dapat mencerminkan keadaan yang sebenarnya.

Validitas instrument menggunakan korelasi skor butir dengan skor total "Product Moment (Pearson)". Analisis dilakukan terhadap semua butir instrument, kriteria pengujiannya dilakukan dengan cara membandingkan $\mathrm{r}$ hitung dengan $\mathrm{t}$ tabel pada taraf tingkat kepercayaan $95 \%, \mathrm{p}=0,05$ atau taraf kepercayaan 99\%, dengan $\mathrm{p}=0,01$. Adapun rumus korelasi Product Moment dari Karl's Pearson (Ghozali dan Fuad, 2008), sebagai berikut :

$$
r_{x y}=\frac{n \sum_{i=1}^{n} X_{i} Y_{i}-\sum_{i=1}^{n} X_{i} \sum_{i=1}^{n} Y_{i}}{\sqrt{\left[n \sum_{i=1}^{n} X_{i}^{2}-\left(\sum_{i=1}^{n} X_{i}\right)^{2}\left[n \sum_{i=1}^{n} Y_{i}^{2}-\left(\sum_{i=1}^{n} Y_{i}\right)^{2}\right]\right.}}
$$

Keterangan:

$\mathrm{r}_{\mathrm{xy}}=$ Koefisien korelasi antara variabel $\mathrm{x}$ dengan variabel $\mathrm{y}$.

$\sum x=$ Jumlah Skor total dari jawaban responden terhadap variabel $\mathrm{x}$.

$\sum y=$ Jumlah Skor total dari jawaban responden terhadap variabel y.

$\mathrm{n} \quad=$ Jumlah responden .

\section{b. Uji Reliabilitas}

Menurut Arikunto (2003:143), reliabilitas berhubungan dengan kepercayaan masyarakat. Reliabilitas merupakan alat untuk mengukur satu set daftar pertanyaan yang merupakan indikator dari variabel-variabel yang diteliti. Untuk mengukur konsistensi konstruk atau variabel penelitian suatu kuisioner dikatakan reliabel atau handal, jika jawaban seseorang terhadap pertanyaan adalah konsisiten atau stabil dari waktu ke waktu.Untuk mengukur reliabilitas dengan uji Cronbach Alpha $(\alpha)$ $>0,600$, selain itu reliabilitas menunjukkan sejauh mana suatu alat ukur dapat dipercaya dan dapat dihandalkan, metode yang digunakan untuk mengukur reliabilitas ini adalah dengan Cronbach Alpha.Adapun yang dimaksud dengan Cronbach Alpha adalah koefesien 
reliabilitas yang menunjukkan seberapa positif hubungan pernyataan-pernyataan yang digunakan dalam instrument pengukuran, seperti yang terdapat pada tabel berikut :

Tabel Tingkat Reliabilitas Berdasarkan Nilai Alpha

\begin{tabular}{||c|l||}
\hline \multicolumn{1}{|c|}{ Alpha } & \multicolumn{1}{|c|}{$\begin{array}{c}\text { Tingkat } \\
\text { Reliabilitas }\end{array}$} \\
\hline \hline 0,00 s.d 0,20 & Kurang Reliabel \\
\hline$>0,20$ s.d 0,40 & Agak Reliabel \\
\hline$>0,40$ s.d 0,60 & Cukup Reliabel \\
\hline$>0,60$ s.d 0,80 & Reliabel \\
\hline$>0,80$ s.d 1,00 & Sangat Reliabel \\
\hline
\end{tabular}

Sumber: Suharsimi Arikunto, (2003 : 170)

\section{Rancangan Analisis dan Uji Hipotesis}

\section{A. Rancangan Analisis}

1. Pengujian Asumsi Dasar Model Struktural

2. Analisis Struktural Equation Modelling

3. Tahap-tahap dalam Structural Equation Modeling :

1. Pengembangan model SEM.

2. Membangun diagram alur (PathDiagram

3. Mengubah diagram alur ke dalam sebuah kumpulan persamaan terstruktur dan persamaan pengukuran.

4. Memilih tipe matrik input dan memperkirakan model yang diajukan.

5. Menaksir identifikasi persamaan model

6. Mengevaluasi kriteria Goodness offit.

7. Uji validitas konstruk dan reliabilitas Dimensi dan Indikator.

8. Interpretasi dan Modifikasi Model

\section{B. Uji Hipotesis}

Pengujian terhadap seluruh hipotesis yang diajukan dalam penelitian ini dilakukan dengan menganalisis nilai CR dan nilai $\mathrm{P}$ dari hasil pengolahan data yang diperoleh untuk kemudian dibandingkan dengan batasan statistik yang diisyaratkan, yaitu di atas 1,96 untuk nilai CR dan dibawah 0,05 untuk nilai $P$. Apabila hasil pengolahan data menunjukkan nilai yang memenuhi syarat tersebut, maka hipotesis penelitian yang diajukan dapat diterima. Pembahasan pada pengujian hipotesis dilakukan secara bertahap sesuai dengan urutan hipotesis yang diajukan.

\section{HASIL DAN PEMBAHASAN}

\section{Uji Validitas Instrumen Penelitian}

Untuk mendapatkan instrumen yang sahih sebagai alat ukur penelitian di lakukan uji validitas, untuk menguji validitas digunakan uji Corelational Product Moment dari Pearson Correlation, dengan cara mengkorelasikan nilai $\mathrm{r}$ product moment untuk setiap butir instrument dengan jumlah total skor setiap butir instrument dari seluruh jawaban responden, (Ghozali dan Fuad,2008). Nilai $\mathrm{r}$ product moment ini selanjutnya dikonsultasikan dengan nilai $\mathrm{r}$ product moment kritis pada tabel statistik dengan $\mathrm{n}$ $=30, \alpha=0,05$. Dengan $\mathrm{n}=30(\alpha=0,05)$ nilai $r$ tabel sebesar 0,361 . Dengan demikian jika nilai $r_{\text {hitung }} \geq 0,361$, maka disimpulkan butir kuesioner tersebut valid. Hasil uji validitas instrumen penelitian dapat disimpulkan bahwa seluruh butir pernyataan pada kuesioner variabel kepemimpinan kepala sekolah, kompetensi guru, motivasi kerja guru ,dan kinerja guru valid, karena seluruhnya memiliki nilai Corrected Item-Total Correlation $\geq$ 0,361 . 


\section{Uji Reliabilitas Instrumen Penelitian}

Untuk melihat keandalan atau reliabilitas instrumen penelitian sebagai alat ukur, jika alat ukur di maksud di gunakan berulang kali memberikan hasil yang relatif sama atau tidak berbeda jauh. Sedangkan untuk uji reliabilitas menggunakan uji Cronbach's Alpha,

\begin{tabular}{|c|c|c|c|c|}
\hline & $\begin{array}{l}\mathrm{S} \\
\mathrm{E}\end{array}$ & C.R & $\mathrm{P}$ & Label \\
\hline MOTIVASI_(Y) <--- $\quad$ KEP_ $_{-}(\mathbf{X} 1)$ & .086 & 2.658 & .008 & par_27 \\
\hline MOTIVASI_(Y) <--- KOMP_(X2) & .076 & 2.492 & .013 & par_28 \\
\hline KINERJA_(Z) <--- MOTIV_(Y) & .081 & 2.242 & .025 & par_15 \\
\hline KINERJA_(Z) <--- KEP_(X1) & .056 & 1.983 & .047 & par_29 \\
\hline KINERJA_(Z) <--- KOMP_(X2) & .099 & 2.944 & .003 & par_30 \\
\hline
\end{tabular}

Adapun yang dimaksud dengan Cronbach Alpha adalah koefesien reliabilitas yang menunjukkan seberapa positif hubungan pernyataan-pernyataan yang digunakan dalam instrument pengukuran. Suatu instrumen dinyatakan reliabel bila koefisien reliabilitas minimal 0,60 (Arikunto,2003 :170). Memperhatikan hasil pengolahan data SPSS yang menggunakan metode Alphacrounbach, maka disimpulkan bahwa seluruh butir pernyataan pada kuesioner variabel kepemimpinan kepala sekolah ,kompetensi guru,motivasi kerja guru, dan kinerja guru reliabel, karena seluruhnya memiliki nilai Corrected Item-Total Correlation $\geq 0,910$.

\section{Hasil Analisis Dan Pengujian Hipotesis}

Pengujian atas 7 (tujuh) hipotesis penelitian.Output SEM Amos overall mode fit regression weights Digunakan untuk menguji tingkat signifikansi ( $p$-value) twotailed, model persamaan struktural disarikan selengkapnya pada tabel berikut:

\section{Tabel Standardized Regression} Weights(Group number 1 - Default model).

\begin{tabular}{|lll|r|}
\hline & & & Estimate \\
\hline MOTIVASI_(Y) & $<---$ & KEPEMIMPINAN_ & .274 \\
MOTIVASI_(Y) & $<---$ & KOMPETENSI_(X2) & .240 \\
KINERJA_(Z) & $<---$ & MOTIVASI_(Y) & .313 \\
KINERJA_(Z) & $<---$ & KEPEMIMPINAN__ & .231 \\
KINERJA_(Z) & $<---$ & KOMPETENSI_(X2) & .633 \\
\hline
\end{tabular}

Output data diolah dengan Amos 18.

Output SEM Amos overall mode fit regression weights).Digunakan untuk menguji tingkat koefisien estimasicritical ratio ( CR )persamaan struktural disarikan selengkapnya pada tabel berikut :

\section{Tabel Standardized Regression}

Weights(Group number Default model).

Dari output squared multiple correlations digunakan untuk melihat besaran variabel eksogen mampu menjelaskan variabel endogen determinan $R$ square pada output squared multiple correlations sebagaimana disarikan dalam tabel di bawah ini :

Tabel Squared Multiple Correlations:

(Group number 1 - Default model)

\begin{tabular}{|l|r|}
\hline & Estimate \\
\hline MOTIVASI_(Y) &, 102 \\
KINERJA_(Z) &, 584 \\
\hline
\end{tabular}

Output Data Diolah Dengan Amos 18

Tabel diatas ,determinan $\mathrm{R}$ square variabel motivasi kerja dijelaskan variabel kepemimpinan kepala sekolah dan kompetensi guru secara bersama-sama sebesar 0,102 atau $10,2 \%$ selebihnya $89,8 \%$ dijelaskan faktor lain di luar model dan determinan $\mathrm{R}$ square variabel kinerja di jelaskan variabel kepemimpinan kepala sekolah, kompetensi guru dan motivasi kerja sebesar 0,584 atau 58,4\% selebihnya $41,6 \%$ di jelaskan faktor lain di luar model. 
Dari output regression weights Pada tabel di atas,dapat di bentuk persamaan sub struktural dan persamaan struktural penelitian sebagai berikut

\section{Persamaan SubStruktural}

Motivasi kerja $=0,274 *$ Kepemimpinan + 0,240*Kompetensi +errorvar 0,898

$\mathrm{R}^{2}=0,102$

\section{Persamaan Struktural}

Kinerja $=0,313 *$ Motivasi $+0,231 *$ Kepemimpinan $+0,633 *$ Kompetensi +errorvar 0,416

$\mathrm{R}^{2}=0,584$

Dasar output SEM Amos pada tabel-tabel di atas, digunakan untuk evaluasihipotesis penelitian sebagai berikut :

\section{Hipotesis 1}

$\mathrm{H}_{0}$ : Tidak terdapat pengaruh kepemimpinan kepala sekolah terhadap motivasi kerja guru di SMP Negeri Kota Palembang.

$\mathrm{H}_{1}$ : Terdapat pengaruh kepemimpinan kepala sekolah terhadap motivasi kerja guru di SMP Negeri Kota Palembang.

\section{Kesimpulan :}

Karena nilai t-Value atau C.R. sebesar 2,658>1,967 atau nilai $\mathrm{P}$ sebesar 0,008 <0,05 (tabel 5.48 halaman 181) maka $\mathrm{H}_{0}$ ditolak, selanjutnya dilihat dari nilai koefisien regresi yang diperoleh positif sebesar 0,274 (tabel 5.47 halaman 180). Dengan hasil tersebut maka dapat disimpulkan :"Terdapat pengaruh positif dan signifikan kepemimpinan kepala sekolah terhadap motivasi kerja

\section{guru di SMP Negeri Kota} Palembang".

\section{Hipotesis 2}

$\begin{aligned} \mathrm{H}_{0}: \text { : } & \text { Tidak terdapat pengaruh } \\ & \text { kompetensi guru terhadap } \\ & \text { motivasi kerja guru di SMP } \\ & \text { Negeri Kota Palembang. } \\ \mathrm{H}_{1} \quad \text { : } & \text { Terdapat pengaruh kompetensi } \\ & \text { guruterhadap motivasi kerja guru } \\ & \text { di SMP Negeri Kota Palembang. }\end{aligned}$

\section{Kesimpulan :}

Karena nilai $t$-Value atau C.R. sebesar 2,492 > 1,967 atau nilai $\mathrm{P}$ sebesar $0,013<0,05$ (tabel 5.48 halaman 181) maka $\mathrm{H}_{0}$ ditolak, selanjutnya dilihat dari nilai koefisien regresi yang diperoleh positif sebesar 0,240 (tabel 5.47 halaman 180). Dengan hasil tersebut maka dapat disimpulkan : "Terdapat pengaruh positif dan signifikan kompetensi guru terhadap motivasi kerja guru di SMP Negeri Kota Palembang”.

\section{Hipotesis 3}

$\mathrm{H}_{0}$ : Tidak terdapat pengaruh kepemimpinan kepala sekolah dan kompetensi gurusecara bersama-sama terhadap motivasi kerja gurudi SMP Negeri kota Palembang.

$\mathrm{H}_{1}$ : Terdapat pengaruh kepemimpinan kepala sekolah dan kompetensi gurusecara bersama-sama terhadap motivasi kerja guru di SMP Negeri kota Palembang.

\section{Kesimpulan :}

Dengan menggunakan analisis SEM Amos, Parameter pengujian squared multiple correlations dengan $\mathrm{R}^{2}$ 
determinan 0,102 (tabel 5.49 halaman 181) dan persamaan substruktural bahwa Motivasi kerja $=$ 0,274* Kepemimpinan $+0,240 *$ Kompetensi + errorvar0,898. Sehingga $\mathrm{H}_{\mathrm{o}}$ ditolak dan $\mathrm{H}_{1}$ dapat diterima, dengan demikian dapat disimpulkan :“Terdapat pengaruh positif dan signifikan kepemimpinan kepala sekolah dan kompetensi guru secara bersamasama terhadap motivasi kerja guru di SMP Negeri kota Palembang”.

\section{Hipotesis 4}

$\mathrm{H}_{0} \quad$ : Tidak terdapat pengaruh motivasi kerja terhadap kinerja guru di SMP Negeri Kota Palembang.

$\mathrm{H}_{1}$ : Terdapat pengaruh motivasi kerja terhadap kinerja guru di SMP Negeri Kota Palembang.

\section{Kesimpulan :}

Karena nilai $t$-Value atau C.R. sebesar 2,242> 1,967 atau nilai Psebesar 0,025 < 0,05 (tabel 5.48 halaman 181) maka $\mathrm{H}_{0}$ ditolak, selanjutnya dilihat dari nilai koefisien regresi yang diperoleh positif sebesar 0,313 (tabel 5.47 halaman 180).Dengan hasil tersebut maka dapat disimpulkan :"Terdapat pengaruh positif dansignifikan motivasi kerja terhadap kinerja guru di SMP Negeri kota Palembang”.

\section{Hipotesis 5.}

$\mathrm{H}_{0}$ : Tidak terdapat pengaruh kepemimpinan kepala sekolah terhadap kinerja guru di SMP Negeri Kota Palembang.

$\mathrm{H}_{1}$ : Terdapat pengaruh kepemimpinan kepala sekolah terhadap kinerja guru di SMP Negeri Kota Palembang.

\section{Kesimpulan :}

Karena nilai t-ValueatauC.R. sebesar 1,983>1,967 atau nilai Psebesar 0,047<0,05 (tabel 5.48 halaman 181) maka $\mathrm{H}_{0}$ ditolak, selanjutnya dilihat dari nilai koefisien regresi yang diperoleh positif sebesar 0,231 (tabel 5.47 halaman 180). Dengan hasil tersebut maka dapat disimpulkan :"Terdapat pengaruh positif dan signifikan kepemimpinan kepala sekolah terhadap kinerja guru di SMP Negeri kota Palembang”.

\section{Hipotesis 6}

$\mathrm{H}_{0}$ : Tidak terdapat pengaruh kompetensi guru terhadap kinerja guru di SMPNegeri Kota Palembang.

$\mathrm{H}_{1}$ : Terdapat pengaruh kompetensi guru terhadap kinerja guru di SMP Negeri Kota Palembang.

\section{Kesimpulan :}

Karena nilai t-Value atau C.R. sebesar 2,944> 1,967 atau nilai $\mathrm{P}$ sebesar $0,003<0,05$ (tabel 5.48 halaman 181) maka $\mathrm{H}_{0}$ ditolak, selanjutnya dilihat dari nilai koefisien regresi yang diperoleh positif sebesar 0,633 (tabel 5.47 halaman 180). Dengan hasil tersebut maka dapat disimpulkan :"Terdapat pengaruh positif dan signifikan kompetensi guru terhadap kinerja guru di SMP Negeri kota Palembang".

\section{Hipotesis 7}


$\mathrm{H}_{0} \quad$; Tidak terdapat pengaruh kepemimpinan kepala sekolah dan kompetensi guru serta motivasi kerja guru secara bersama-sama terhadap kinerja guru di SMP Negeri Kota Palembang.

$\mathrm{H}_{1}$ : Terdapat pengaruh kepemimpinan kepala sekolah dan kompetensi guru serta motivasi kerja guru secara bersama-sama terhadap kinerja gurudi SMP Negeri Kota Palembang.

\section{Kesimpulan :}

Dengan menggunakan analisis SEMAmos, Parameter pengujian squared multiple correlations dengan $\mathrm{R}^{2}$ determinan 0,584 (tabel 5.49 halaman 181) dan persamaan struktural bahwa Kinerja $=0,313 *$ Motivasi $+0,231 *$ Kepemimpinan + 0,633* Kompetensi +errorvar 0,416.Sehingga $\mathrm{H}_{\mathrm{o}}$ ditolak dan $\mathrm{H}_{1}$ dapat diterima, dengan demikian dapat disimpulkan: “Terdapat pengaruh positif dan signifikan kepemimpinan kepala sekolah, kompetensi guru serta motivasi kerja guru secara bersama-sama terhadap kinerja guru di SMP Negeri Kota Palembang”.

\section{KESIMPULAN DAN SARAN}

\section{Kesimpulan Penelitian :}

1. Terdapat pengaruh kepemimpinan kepala sekolah terhadap motivasi kerja guru SMPN Kota Palembang dimensi dari variabel kepemimpinan kepala sekolah dominan adalah hubungan manusia (HM) Dan indikator dominan pada pimpinan memiliki hubungan kesejawatan yang baik dengan guru (HM1)

2. Terdapat pengaruh kompetensi guru terhadap motivasi kerja guru SMPN Kota Palembang dimensi dari variabel kompetensi dominan adalah kepribadian (kp) dan indikator dominan pada kp1 kepribadian yang mantab

3. Terdapat pengaruh kepemimpinan kepala sekolah terutama pada dimensi hubungan manusia dan kompetensi guru terutama pada dimensi kepribadian secara bersama-sama terhadap motivasi kerja guru terutama pada dimensi kekuasaan SMPN Kota Palembang, sesuai dengan determinasi $\mathrm{R}$ square sebesar 0,102 atau $10,2 \%$. Sehingga $89,8 \%$ nya lagi motivasi kerja di pengaruhi variabel lain di luar konstruk penelitian. Variabel yang paling dominan mempengaruhi motivasi kerja guru adalah variabel kepemimpinan kepala sekolah dengan koefisien 0,274.

4. Terdapat pengaruh motivasi kerja guru terhadap kinerja guru SMPN Kota Palembang Dimensi motivasi kerja dominan adalah kekuasaan dan indikator dominan KE.1 berusaha agar dirinya di hargai.

5. Terdapat pengaruh kepemimpinan kepala sekolah terhadap kinerja guru SMPN Kota Palembang dimensi kepemimpinan kepala sekolah dominan adalah hubungan manusia (HM) indikator dominannya adalah pimpinan memiliki hubungan kesejawatan yang baik dengan guru.

6. Terdapat pengaruh kompetensi guru terhadap kinerja guru SMPN Kota Palembang dimensi kompetensi guru dominan adalah kepribadian dan 


\section{indikator dominan adalah kepribadian yang mantap.}

7. Terdapat pengaruh kepemimpinan kepala sekolah terutama pada dimensi hubungan manusia, kompetensi guru terutama pada dimensi kepribadian dan motivasi terutama pada dimensi kekuasaan secara bersama-sama terhadap kinerja guru terutama pada dimensikemampuan kerjaSMPN Kota Palembang sesuai dengan Output Amos menunjukkan dengan output $R$ square sebesar 0,584 sedangkan 41,6\% lainnya, kinerja di pengaruhi oleh variabel lain diluar konstruk penelitian.

\section{Variabel yang paling dominan mempengaruhi kinerja adalah variabel kompetensi guru dengan koefisien 0,633.}

\section{SARAN}

1. Kepemimpinan kepala sekolah SMPNegeri di Kota Palembang sudah relatif baik sehingga akan mampu memberikan peningkatan pada kinerja guru dalam melaksanakan proses pembelajaran. Beberapa indikator kepemimpinan kepala sekolah yang di sarankan untuk tetap di pertahankan terutama pada indikator pimpinan memiliki hubungan kesejawatan yang baik dengan guru,pimpinan saling mempercayai kepada guru, penyusunan rencana kerja, prosedur pencapaian tujuan.

2. Kompetensi guru SMP Negeri di kota Palembang sudah relatif tinggi sehingga akan mampu memberikan peningkatan pada kinerja guru dalam melaksanakan proses pembelajaran. Beberapa indikator kompetensi guru yang di sarankan untuk tetap dipertahankan terutama pada indikator pengembangan kurikulum, pelaksanaan pembelajarannya mendidik, kepribadian yang mantab, kepribadian yang stabil, menggunakan teknologi komunikasi dan informasi, bergaul secara efektip dengan peserta didik, konsep dengan materi ajar, kurikulum sekolah.

3. Motivasi kerja guru SMP Negeri di kota Palembang sudah relatif tinggi sehingga akan mampu memberikan peningkatan pada kinerja guru dalam melaksanakan proses pembelajaran. Beberapa indikator motivasi kerja guru yang di saran kan untuk tetap dipertahankan terutama pada indikator upaya untuk tidak ketinggalan oleh guru lain dalam prestasi, upaya mendapatkan hasil kerja, semangat untuk bekerja sama, sesama mematuhi segala aturan yang ada,usaha untuk menjaga persahabatan dengan teman sekerja, berusaha agar dirinya di hargai,dan berupaya untuk tidak di remehkan .

4. Kinerja guru SMP Negeri di kota Palembang sudah relatif tinggi dalam melaksanakan pembelajaran.Beberapa indikator kinerja guru SMP Negeri kota Palembang yang di saran kan untuk tetap dipertahankan terutama pada indikator merencanakan program pengajaran dengan tepat,berhati-hati dalam menjelaskan materi ajaran ,menerapkan hal-hal baru dalam pembelajaran,menyelesaikan program pengajaran sesuai dengan kalender akademik,menggunakan media dalam pembelajaran dan menyelenggarakan administrasi sekolah dengan baik 
DAFTAR PUSTAKA

Arikunto,Suharsimi,2003, Dasar-Dasar Evaluasi Pendidikan, Jakarta: PT.Bumi Aksara

Dinas Pendidikan, Pemuda Dan Olahraga Kota Palembang, 2011

Efendi, A. 2007. Revolusi Kecerdasan Abad 21 (Kritik MI, EI, SQ, AQ, dan Successful Intelegence atas IQ). Alfabeta.Bandung

Kartono, 2007. Tinjauan Politik Mengenai Sistem Pendidikan Nasional.

Jakarta: Anem Kosong Anem

Owens, 2001. Organizational Behaviour In Education Fourth Edition
International Edition Englewood Cliffs, Prentice-Hall

Muhibbin, syah, 2007. Psikologi Pendidikan. Bandung : PT. Remaja Rosdikarya

Mc Clelland, 2001, Memacu Masyarakat Berprestasi : Mempercepat Laju Pertumbuhan Ekonomi Melalui Peningkatan Motif Berprestasi, Jakarta:Intermedia.

Mitchell, Terence, 2010. People in Organization Understanding Their Behaviour, Prentice Hall of India Private Limited, New Delhi.

Ghozali, dan Fuad. 2008. Structural Equation Modelling Teori, Konsep dan Aplikasi. Semarang. Universitas Diponegoro. 